\section{日本臨床外科学会山梨県支部抄録 (第82回山梨県臨床外科医学会)}

\author{
会 期：令和 2 年 9 月 19 日（土） \\ $14: 00 \sim 17: 00$ \\ 会場 : 山梨大学医学部臨床大講堂 \\ 当番世話人：都留市立病院 外科 岡本 廣挙
}

1 結核性左鎖骨上リンパ節炎を合併しリンパ節転移評価 に難渋した早期胃癌の 1 例

山梨大学医学部付属病院臨床研修センター1, 山梨大学医学部第 一外科 2

岩田千優 ${ }^{1}$, 庄田勝俊 ${ }^{2}$, 赤池英憲 ${ }^{2}$, 仲山 孝 $^{2}$, 高橋和徳 ${ }^{2}$, 河口

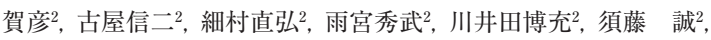
井上慎吾 ${ }^{2}$, 河野 寛 $^{2}$, 板倉 淳 ${ }^{1}$ ，市川大輔 ${ }^{2}$

症例は82歳男性。検診の上部消化管内視鏡検查で胃癌を指摘され 手術目的に当科紹介となった。cT 1 b,cN 0 ,cStage I と診断され たが、造影 CTで左鎖骨上リンパ節腫大、PET-CTで同リンパ節 にFDGの集積を認めた。原発巣所見との乘離から病理診断が必 要と考え、左鎖骨上リンパ節に対し吸引針細胞診を 2 回施行し確 定診断が得られず、摘出生検を行った結果、抗酸菌染色陽性、 Langhans型巨細胞を伴う類上皮細胞肉芽腫と診断された。血液 検査で結核 QFT陽性であり、結核性リンパ節炎と考えられた。 喀痰培養、結核菌核酸 PCR 検査は陰性であり、活動性のない結 核既感染と診断し、胃癌に対し腹腔鏡下幽門側胃切除術を施行し た。術後経過は良好で再発所見なく、外来経過観察中である。

今回我々は、結核性左鎖骨上リンパ節炎を合併し、転移との鑑 別に難渋した早期胃癌の 1 例を経験したので文献的考察を加え報 告する。

\section{2 小細胞肺癌の術前検查で発見された男性乳癌の 1 例}

山梨大学医学部第一外科

樋口雄大, 中山裕子, 大森征人, 木村亜矢子, 井上慎吾, 庄田勝 俊, 古屋信二, 赤池英憲, 細村直弘, 河口賀彦, 雨宮秀武, 須藤 誠, 川井田博充, 河野 寛, 板倉 淳, 市川大輔

【症例】86歳男性、前医で左肺下葉結節を指摘され、小細胞肺癌 疑いで当院へ紹介となった。PET-CT検査を施行したところ、 肺癌の他に、女性化乳房と左乳房 CD 区域の集積を認め当科紹介 となった。触診で左乳房 C区域に可動性良好、弾性硬の腫瘤を触 知し、マンモグラフィ検查では左 $\mathrm{U}-\mathrm{O}$ 領域に腫瘤影を認めカテ ゴリー 4 とした。乳房超音波検查では左 C 区域に $15 \mathrm{~mm}$ 大の囊胞 性腫瘤を認め、前方境界線は断裂し、血流豊富で、エラストグラ フィスコアは 5 であった。造影 CT 検査で有意なリンパ節腫大や 遠隔転移は認めず、穿刺吸引細胞診はclass IVであった。乳癌の 診断で左乳房全切除術を施行した。センチネルリンパ節生検は年 齢を考慮し施行せず、病理診断は非浸潤性乳管癌であった。

【まとめ】男性乳癌は乳癌全体の $1 \%$ 以下と稀である。今回我々は、 他臓器癌の精查中に発見された男性乳癌の 1 例を経験したので、 過去症例との比較、ならびに文献的考察を踏まえて報告する。
3 肝門部胆管原発の小細胞型神経内分泌癌の一例

山梨大学医学部附属病院臨床研修センター1, 山梨大学医学部第 一外科 ${ }^{2}$

川村知輝 ${ }^{1}$, 雨宮秀武 ${ }^{2}$, 細村直弘 ${ }^{2}$, 川井田博充 ${ }^{2}$, 河野 寛 ${ }^{2}$, 肥 田 樹 ${ }^{2}$, 三枝悠人 ${ }^{2}$, 樋口雄大 ${ }^{2}$, 仲山 孝 ${ }^{2}$, 高橋和德 ${ }^{2}$, 芦沢直樹 ${ }^{2}$,

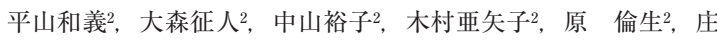
田勝俊 ${ }^{2}$, 古屋信二 ${ }^{2}$, 赤池英憲 ${ }^{2}$, 河口賀彦 ${ }^{2}$, 須藤 誠 $^{2}$, 井上慎吾 ${ }^{2}$, 市川大輔 2

症例は72歳、男性。体調不良と黄疸を主訴に前医を受診。肝門部 胆管癌による閉塞性黄㾝の診断で加療目的に当院紹介となった。 CT で左右肝管合流部から膵上縁まで胆管壁の肥厚を認め、膵上 縁にリンパ節の腫大を認めた。ENBD 造影では右肝管壁にも固さ を認めた。Bismuth III a 型の肝門部胆管癌 T 2 a,N $1, \mathrm{M} 0$, cStage III B と診断した。右肝の門脈塞栓術を施行後、拡大右肝 切除十肝外胆管切除を施行した。術後経過良好で第16病日退院と なった。病理診断はSmall cell neuroendocrine carcinoma T2 a,N 1 ,M 0 ,pStage III Bであり、術後補助化学療法として CDDP +VP16を 6 コース施行する方針とした。現在 2 コース終了し、 無再発生存中である。胆管原発の悪性腫瘍は大部分が腺癌で小細 胞型神経内分泌癌は非常に稀である。膵・消化管神経内分泌腫瘍 ガイドラインでは、神経内分泌がんを切除した場合、肺小細胞が んに準じたプラチナ系薬剤を用いた術後補助療法を行うことが推 奨されている。この点が、通常の胆管がんと異なることを認識し ておく必要がある。

4 繰り返す急性膵炎を契機に診断された膵管内乳頭粘液 性腺癌の一例

山梨病院外科 - 消化器外科 ${ }^{1}$, 東京女子医科大学病院消化器 - 一 般外科 ${ }^{2}$, 山梨病院消化器内科 ${ }^{3}$, 山梨病院病理診断科 4

出雲 渉 ${ }^{1,2}$, 土屋雅人 ${ }^{1}$, 曽田 均 ${ }^{1}$, 見本雄一郎 ${ }^{3}$, 白勢大門 ${ }^{3}$, 若 尾聡士 ${ }^{3}$, 小澤俊一郎 ${ }^{3}$, 末木良太 ${ }^{3}$, 進藤邦明 ${ }^{3}$, 中村暢樹 ${ }^{4}$, 佐藤 公 ${ }^{3}$, 小澤俊総 ${ }^{4}$, 山本雅一 ${ }^{2}$

【はじめに】膵管内乳頭粘液性腫瘍 (IPMN) は経時的にlowgrade dysplasiaから high-grade dysplasia, invasive Intraductal Papillary Mucinous Carcinoma (IPMC) に変化していく腫瘍で ある。今回、繰り返す急性膵炎を契機に診断された invasive IPMCの 1 例を経験したので報告する。

【症例】症例は55歳女性。10年前から繰り返す急性膵炎で入院加 療を繰り返しており、経時的な画像を確認すると、無症状時の CT, MRIでは閉塞起点を伴わずに膵体尾部の主膵管が $8 \mathrm{~mm}$, 主 膵管と交通を有する膵体部の分枝膵管が $20 \mathrm{~mm}$ に拡大しており、 明らかな壁在結節は認めなかった。EUS, ERPは患者様ご希望さ れず未施行で、術前CA19-9 は38 U/mlであった。混合型IPMN が背景にあり急性膵炎を繰り返していたとの診断に対し尾側膵切 除十脾摘出術を施行した。

術中所見では膵は全体として腫大・硬化を認め、周囲に膵炎の影 響と考えられる癒着を中等度認めた。門脈直上（膵厚さ $20 \mathrm{~mm}$ ) でエンドGIAリンフォースブラックを用いて膵をゆっくり圧挫・ 切離（計12分）し、頭側膵断端は術中迅速診断で断端陰性を確認 とした。手術時間 252 分、出血 $50 \mathrm{ml}$ 。術後 3 日目に左横隔膜下に 留置したドレーンを抜去し、経過良好で術後13日目に退院となっ た。病理組織学的にはgastric type, mixed typeで一部に浸潤部 を認め、invasive IPMC, TS 1 (15mm), i-TS (0.1mm), T 1 a N 0 , M 0, Stage I A, R 0、術後33日目から補助化学療法 (S- 1 : $120 \mathrm{mg} /$ body）導入中である。

【まとめ】繰り返す急性膵炎を契機に診断されたinvasive IPMC 
と診断された 1 例を経験したので若干の文献的考察を加えて報告 する。

5 慢性炎症による小腸狭窄により小腸穿孔をきたした 1

例

都留市立病院外科

柴 修吾, 川島健司, 媣澤敏男, 岡本廣挙

小腸穿孔は消化管穿孔の中でも比較的稀である。今回我々は、慢 性炎症による小腸狭窄により小腸穿孔を来した 1 例を経験したの で報告する。症例は69歳、男性。前日からの下腹部痛を主訴に来 院した。腹部造影 CT 検查では部分的な小腸壁の拡張とその肛門 側腸管の壁肥厚を認め小腸周囲にわずかな腸管外ガスが確認され た。小腸穿孔の診断で同日緊急手術を行った。腹腔内は黄色の腹 水で污染されていた。小腸に硬化した部分を認めその口側腸管は 拡張していた。穿孔部は確認できないものの、腸間膜内に気腫を 認め小腸穿通が考えられた。回腸部分切除およびドレナージを施 行した。切除標本の眼的所見では、粘膜面に多発の潰瘍痏痕を認 め一部は狭窄を来していた。狭窄部のすぐ口側に穿孔部が確認さ れた病理検査では潰瘍周囲粘膜内に多数の好酸球浸潤が認められ 好酸球性腸炎が考えられた。術前に小腸穿孔と診断しえた症例を 経験したため報告する。

\section{6 ロボット支援下に摘出した肺軟骨腫の一例}

\section{山梨大学医学部第二外科}

武藤 護, 佐藤大輔, 大貫雄一郎, 内田 嚴, 松原寛知, 中島博之 症例は21歳、女性。2 年前、咳嗽を主訴に近医を受診し、胸部 CT 画像で右肺 S 8 に $2 \mathrm{~cm}$ の境界明瞭な結節影を指摘された。 PET/CTではFDG集積がSUVmax 0.98 と軽度であったため、外 来で経過観察をされていた。2 年の経過で右肺 S 8 の結節影の増 大傾向と右肺 S 9 に $1.2 \mathrm{~cm}$ の新たな結節影を認めたため、診断治 療目的に当科紹介となった。既往歴は喘息のみで、術前検査では 異常所見を認めなかった。手術はロボット支援下に右肺下葉切除 術を施行した。病理組織検查では、腫瘍はどちらも硝子軟骨が主 体で、内部には骨組織、脂肪組織が増生しており、悪性所見は認 めず、肺軟骨腫と診断した。肺軟骨腫はCarney`s triadの部分症 とされ、消化管GIST、副腎外paragangliomaの合併が報告され ているが、本症例では現在のところ指摘されていない。各徴候の 出現はかなり長期間をおいて認められることも多く、今後の経過 観察が必要であると考えられる。

7 インドシアニングリーン蛍光ナビゲーションロボット 支援下肺区域切除

山梨大学医学部第二外科

佐藤大輔, 大貫雄一郎, 内田 嚴, 松原宽知, 中島博之

症例は63歳、女性。健診で胸部異常陰影を指摘され、前医を受診 した。胸部CT 画像で左肺 $\mathrm{S} 6 \mathrm{a}$ に全腫瘍径 $1.6 \mathrm{~cm}$ 、充実径 $0.3 \mathrm{~cm}$ の part solid GGNを認め、診断治療目的に当科に紹介となった。 手術はロボット支援下でアプローチした。上下葉間の分葉は良好 で、腫瘍はS 6 a 頂部に位置し、術前のCTで大部分がすりガラス 影の part solid GGNであったため、積極的縮小手術としてインド シアニングリーン (ICG) 蛍光ナビゲーションを用いた左肺 S 6 区域切除術を施行した。区域間の同定方法としては、以前から主 として含気虚脱ラインを利用した方法が用いられてきたが、気腫 性変化が強い肺では区域間が不明瞭になることが多かった。2018 年にICGの「血管及び組織の血流評価」が適応に追加され、ICG
蛍光ナビゲーションを用いた肺区域切除の良好な成績が報告され ている。文献的考察を加えて報告する。

8 大動脈弁輪拡張を来した15歳、男児のMarfan症候群 に対して自己弁温存大動脈基部置換術を施行した 1 例 山梨大学医学部第 2 外科

荻原千恵, 四方大地, 吉田幸代, 河合幸史, 白岩 聡, 本田義博, 村田眞哉, 榊原賢士, 加賀重覀喜, 中島博之

Marfan 症候群患者にしばしばみられる大動脈弁輪拡張症（annuloaortic ectasia：AAE）に対する従来の標準術式は、人工弁付き 人工血管を用いた大動脈基部置換手術（Bentall 手術）であった。 しかし、機械弁使用においては生涯にわたる warfarin 内服に伴 う出血、血栓症や若年女性では月経過多や催奇形性などの問題が ある。生体弁使用においては人工弁の耐久性から 5 年から 15 年程 度の経過で再手術が必要になる。近年では、このような人工弁関 連合併症を回避するべく自己弁温存大動脈基部置換手術（valvesparing aortic root replacement：VSRR）が積極的に行われるよ うになっている。今回われわれはAAEを合併したMarfan症候 群の小児例に対しVSRRを施行したので報告する。症例は15歳、 男児。 4 年前に水晶体脱臼を契機にMarfan症候群と診断され、 同時に大動脈弁輪拡張を指摘された。経時的拡大を示し、Valsal$\mathrm{va}$ 洞径が $46.2 \mathrm{~mm}$ となったため手術適応と判断された。術中所見 では、大動脈弁は 3 尖で弁尖自体の器質的変化はなかった。自己 弁温存が可能と判断し、28mm の Valsalva graft (Gelweave, TERUMO社）を用いてVSR（aortic reimplantation法）を施行 した。経過良好で術後第10病日に自宅退院となった。半年後の心 エコー検査では自己大動脈弁に変形や逆流は認めていない。若干 の文献的考察を加えて報告する。

9

例

山梨厚生病院外科

水上瑛仁, 加藤大貴, 天白典秀, 宮原和弘, 飯塚 恒, 山寺陽一 噴門側胃切除術後の再建方法として食道残胃吻合、ダブルトラク 卜法、空腸間置換法などが行われているが、術後逆流性食道炎等 によるQOL低下や、近年普及しつつある腹腔鏡下手術において は手技の煩雑さが問題となる。当院では2020年より腹腔鏡下噴門 側胃切除術においてSOFY (side overlap with fundoplication by Yamashita）変法による食道残胃吻合を導入し、現在までに 3 例 施行した。全例男性で平均年齢76歳 (67-82歳)、病変部は 3 例 とも U Less、病期はpStage I A、平均手術時間は250分 (220-271 分)、吻合時間は78分 (67-94分)、出血量は30ml (10-60ml) で あった。術後縫合不全、逆流症状は無く、平均術後在院日数は 17 日（14-19日）であった。SOFY変法は手技の簡便さ、術後 QOL において満足できる再建方法と思われた。

10 傍ストーマ・左鼠径・会陰のヘルニアに対して同時へ ルニア根治術を施行した一例

山梨大学医学部第一外科

肥田 樹, 古屋信二, 平山和義, 滝口光一, 原 倫生, 須藤 誠, 三枝悠人, 樋口雄大, 仲山 孝, 中田晴夏, 斎藤 亮, 山本淳史, 高橋和徳, 芦沢直樹, 大森征人, 中山裕子, 木村亜矢子, 庄田勝 俊, 細村直弘, 雨宮秀武, 赤池英憲, 河口賀彦, 川井田博充, 井 上慎吾, 河野 宽, 市川大輔

症例は70歳代の男性. X- 1 年 4 月に直腸癌に対して腹腔鏡下直 
腸切断術 (Rb, Type 1, mod/wel, T 1 b (SM), Ly 0, V 1 a, N $0, \mathrm{M} 0$, pStage I）を行った。同年 9 月に傍ストーマヘルニアを 認め、傍ストーマ修復術（単純縫合閉鎖のみ）を施行した。同年 12月より傍ストーマヘルニア再発あり。また会陰ヘルニアと左鼠 径ヘルニアを認めた。本人の希望で同時に根治術を行う方針とな つた。X年 7 月に手術を施行した。傍ストーマヘルニアに対して Sugarbaker法、左鼠径ヘルニアに対して Lichtenstein法、会陰 ヘルニアに対して経会陰式のメッシュを用いたヘルニア根治術を 施行した。術後経過問題なく術後 8 日目に退院となった.

今回、傍ストーマ・左鼠径・会陰のヘルニアに対して同時ヘルニ ア根治術を施行した一例を経験したので若干の文献的考察を加え 報告する。

\section{1 膵原発の anaplastic carcinoma の 1 例}

市立甲府病院外科 ${ }^{1}$, 山梨大学医学部第一外科 ${ }^{2}$

古谷元宏 ${ }^{1}$, 福島久貴 ${ }^{1}$, 松岡弘泰 ${ }^{1}$, 若菜弘幸 ${ }^{1}$, 丸山孝教 ${ }^{1}$, 千須 和寿直 ${ }^{1}$, 角田 元 $^{1}$, 飯野 弥 $^{1}$, 川井田博充 ${ }^{2}$, 市川大輔 ${ }^{2}$

症例：72歳、男性。腹部膨満を主訴に近医受診し、CTにて約 $70 \mathrm{~mm}$ 大の膵体部腫瘤を認め当院紹介。精査の結果、膵体尾部癌 cT 3 (TS 4 (70mm) ) CH 0 ,DU $0, \mathrm{~S} 1$,RP 1 ,PV 1 (PVsp) ,A 1 (Asp) ,PL 0,OO 1 (胃＋結腸)) N 1 aM 1 PER s/o と術前 診断し、開腹手術にて明らかな播種転移を認めないことを確認し た後、膵体尾部切除術および胃全摘術を施行した。

術後の病理組織学的検査で、大型の高度異型な核を持つ多形性を 示す細胞や紡錘型細胞、破骨型多核巨細胞を認めた。免疫染色で はCD68が破骨型多核巨細胞に（+）であり、anaplastic carcinoma with osteoclast-like giant cells と診断された。

最終診断はPbt, TS 4 (105mm), nodular type, med, INFb, ly 1 v 1 , ne $0, \operatorname{mpd} 0, \mathrm{pT} 3, \mathrm{pS} 1, \mathrm{pRP} 1, \mathrm{pPV} \mathrm{sp} 1, \mathrm{pA} 0, \mathrm{pPL} 0$, pOO 1 （胃）, pPCM 1, pDPM 0, R 1, pN 1 b, pStage II Bであ った。

今後、化学療法を行っていく予定である。

今回我々は稀な膵anaplastic carcinomaの 1 例を経験したので、 若干の文献的考察を加え、報告する。

12 腋窩リンパ節転移で発見された原発不明癌の 1 例 山梨大学医学部第一外科 ${ }^{1}$, 同病理診断科 ${ }^{2}$

石井結子 ${ }^{1}$, 井上慎吾 ${ }^{1}$, 樋口雄大 ${ }^{1}$, 大森征人 ${ }^{1}$, 中山裕子 ${ }^{1}$, 木村 亜矢子 1 , 大館 徹 ${ }^{2}$, 市川大輔 1

原発不明癌は癌全体の $1 \sim 5 \%$ を占め、一般的には予後不良であ る。今回我々は、乳房に明らかな原発所見がなく、腋窩リンパ節 のみに転移を認めた乳癌の 1 例を経験したので報告する。42歳女 性。人間ドッグの乳腺超音波検査で右腋窩に $53 \mathrm{~mm}$ のリンパ節腫大 を指摘された。画像所見上、他に転移巣を認めず、原発不明癌の リンパ節転移、又は悪性リンパ腫が疑われ、精查加療目的に当院 を受診した。リンパ節生検を行い、術中の迅速病理診断で乳癌の 転移と診断されたため、右腋窩郭清を追加で行った。病理診断で、 T 0 N 1 M 0 , stage I A, ER (90\%), PgR ( $0 \%)$, HER 2 ( 1 +), Ki67 (40\%), GATA 3 (陽性) でルミナールB乳癌と診断 された。術後補助療法として AC療法を行っている。稀な 1 例 を経験したので文献的考察を加えて報告する。
13 仙骨前面に発生した成熟奇形腫の 1 例 山梨大学医学部附属病院臨床研修センター1, 山梨大学医学部第 一外科 ${ }^{2}$

土田哲司 ${ }^{1}$, 古屋信二 ${ }^{2}$, 平山和義 ${ }^{2}$, 須藤 誠 $^{2}$, 肥田 樹 ${ }^{2}$, 滝口 光一 ${ }^{2}$, 原 倫生 ${ }^{2}$, 三枝悠人 ${ }^{2}$, 樋口雄大 ${ }^{2}$, 仲山 孝 $^{2}$, 山本淳史 ${ }^{2}$, 斉藤 亮 $^{2}$, 高橋和德 ${ }^{2}$, 芦沢直樹 ${ }^{2}$, 大森征人 ${ }^{2}$, 中山裕子 ${ }^{2}$, 木村

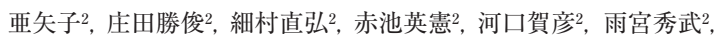
川井田博充 ${ }^{2}$, 井上慎吾 ${ }^{2}$, 河野 宽 ${ }^{2}$, 市川大輔 ${ }^{2}$

症例は40歳、女性。以前より検診にてCA19-9 の高值を指摘さ れていた。前医で施行したCT と MRI検查にて仙骨前面に $5 \mathrm{~cm}$ 大の多房性囊胞性腫瘤を認め、Tailgut cyst 疑いの診断で当科紹 介となった。増大傾向があり悪性化も否定できず、経仙骨的腫瘤 摘出術を施行した。腫瘤は尾骨先端と強く癒着しており、尾骨も 一部合併切除した。病理診断では、重層扁平上皮·円柱上皮·粘 液性上皮に被覆された囊胞性病変であり、壁内に平滑筋組織・末 梢神経繊維・汗腺様腺管構造を認めることから成熟奇形腫と診断 された。仙尾部に発生する囊胞性腫瘤は他に臂部皮様囊腫、類表 皮囊腫、傍直腸膿などがある。画像診断での鑑別が困難で、悪性 化が報告されているものもあり、腫瘍を遺残させることなく切除 することが重要である。今回我々は、成人においては非常に稀な 仙尾部奇形腫を経験したので、若干の文献的考察を加えて報告す る。 